\title{
Changes in Agriculture and Rural Employment in Southwestern Thuringia, Germany
}

\author{
Mitsuru Yamamoto \\ Faculty of Liberal Arts, Saitama University, Urawa, Saitama 338-8570, Japan
}

\begin{abstract}
Population loss, the movement of young and middle aged people into occupations outside of agriculture, and the aging of LPG workers had been conspicuous in the rural areas of southwest Thuringia in former East Germany even before reunification. Aging of agricultural workers and acquisition of side jobs by members of farm households, processes similar to those occurring in West Germany and other industrial countries, had already begun. We investigated the employment situation in one particular village close to the former east-west border. Here, some young people were able to continue in their old occupations in the East even after reunification, while those who lost their jobs looked for employment in Bavaria, in former West Germany. They too often found occupations in which they could use their previously learned skills. The local LPG, on the other hand, was turned into a cooperative, which rehired for the most part young skilled workers, while the older generation was let go and went into retirement. There are now only two independent farms and one farmer who has rented his land out to a Bavarian lessee; all other land is rented by the local cooperative. In spite of the political changes the occupational structure of the area, agriculture with subsidiary employmentmultiple job-holding farming-remains basically unaltered. We suggest that the equal division inheritance system, leading to small scale farms, and the existence of traditional manufacturing industries, etc., conditions that distinguish this region from the North of former East Germany, have sustained this structure. The location, close to the former border and resulting employment opportunities in the West, that became available with reunification, probably provide significant support for it. The rural area of southwestern Thuringia should thus be understood as having a character which is markedly distinct from that of the North of former East Germany.
\end{abstract}

Key words: reunification, Germany, LPG, cooperative, multiple job-holding farming

\section{Introduction}

North and South of the border region along the old east-west boundary in Germany differ in various points. The North is flat, and the main industry is agriculture, which is traditionally in the hands of large landowners. In the West large cities like Hamburg are close. The South on the other hand is hilly or mountainous and while small scale farms predominate, one can also find handicrafts and a developed manufacturing industry. As opposed to the North, there are no large cities on the western side.

When considering the changes in the former border areas one has to pay close attention to how these differing regional conditions affect the unfolding of phenomena. A further point of interest is whether the border areas in the South show similar tendencies as areas with like characteristics in former West Germany.

The purpose of this study is to elucidate the change in the employment situation before and after reunification in the rural area of southwestern Thuringia, which lies across the southern part of the old border from Bavaria. The data is based on interviews with members of each household in the sample community, which were conducted in August 1993, as well as on materials and statistics from the Ministry of Agriculture and Forestry of the State of Thuringia and various other relevant institutions. The sample community, the village of Eicha, lies in southwestern Thuringia. Because Eicha is located close to the border of the State of Bavaria, it must be influenced by the opening 


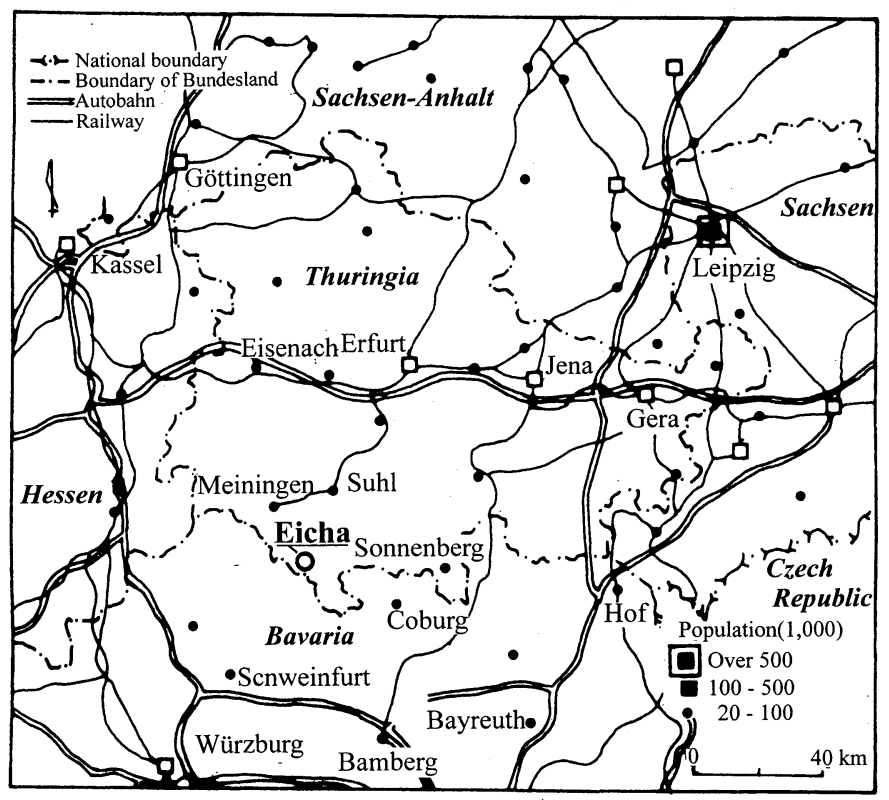

Figure 1. Map of the study area

of the border. It had, in 1993, 71 households with a total population of 263 (cf. Fig. 1) ${ }^{1}$.

\section{Employment in industry and agriculture in Thuringia}

Conditions for agriculture vary across the State of Thuringia, but differ from those of East of the Elbe river in the North of former East Germany where big scale farms predominate. The fact that, in contrast to the North, equal division inheritance was the main traditional inheritance system in Thuringia, has led to the fragmentation of land. Except for the Thüringen Basin, which has loess, soil conditions are poor. The fertility index (Ertragsmesszahl) in Thuringia tends to be around 50, except for the basin, and falls to below 30 in the Southwest (Heunemann, 1992, p. 100).

Because of these circumstances, small-scale farming supplemented with non-agricultural employment came to predominate. Handwork in Thüringer Wald has provided employment for small-scale farmers (Sasaki, 1994). With rich resources of wood and iron in this region, for example, guns and other machines have been manufactured in Suhl, toys in Sonnenberg, glass in Lauscha, and other native industries since the $16^{\text {th }}$.
One can deduce the lesser importance of agriculture in Thuringia from the proportion of the total working population employed in it. The percentages were, in 1986, in the northern districts of East Germany, 25.3\% for Neubrandenburg, 20.6\% for Schwerin, while the district of Erfurt, which includes the Thüringer Basin had $10.7 \%$, Gera in the Southeast of Thuringia had $8.8 \%$ and Suhl in the Southwest 6.5\% (Scherf, 1990 , p. 221), showing a clear difference between North and South.

The level of unemployment in the urban industrialized regions of Thuringia from Jena to Erfurt is currently relatively low. This applies as well to the agricultural areas close to the border of Bavaria (Fig. 2). By contrast, it is high in the agricultural area in the North of the Thüringer Basin and in the mountains of the Thüringer Wald. Industrial restructuring is making progress in the urban areas of Jena and Erfurt. While employment is increasing there, native industries in the mountainous areas are decaying and reconstruction is difficult. One may assume that, by contrast, in areas close to Bavaria, employment opportunities offered there resulted in lower unemployment rates.

Table 1 shows the numbers of commuters from former East Germany to northern Bavaria in 1992. It shows that there were far more, in 


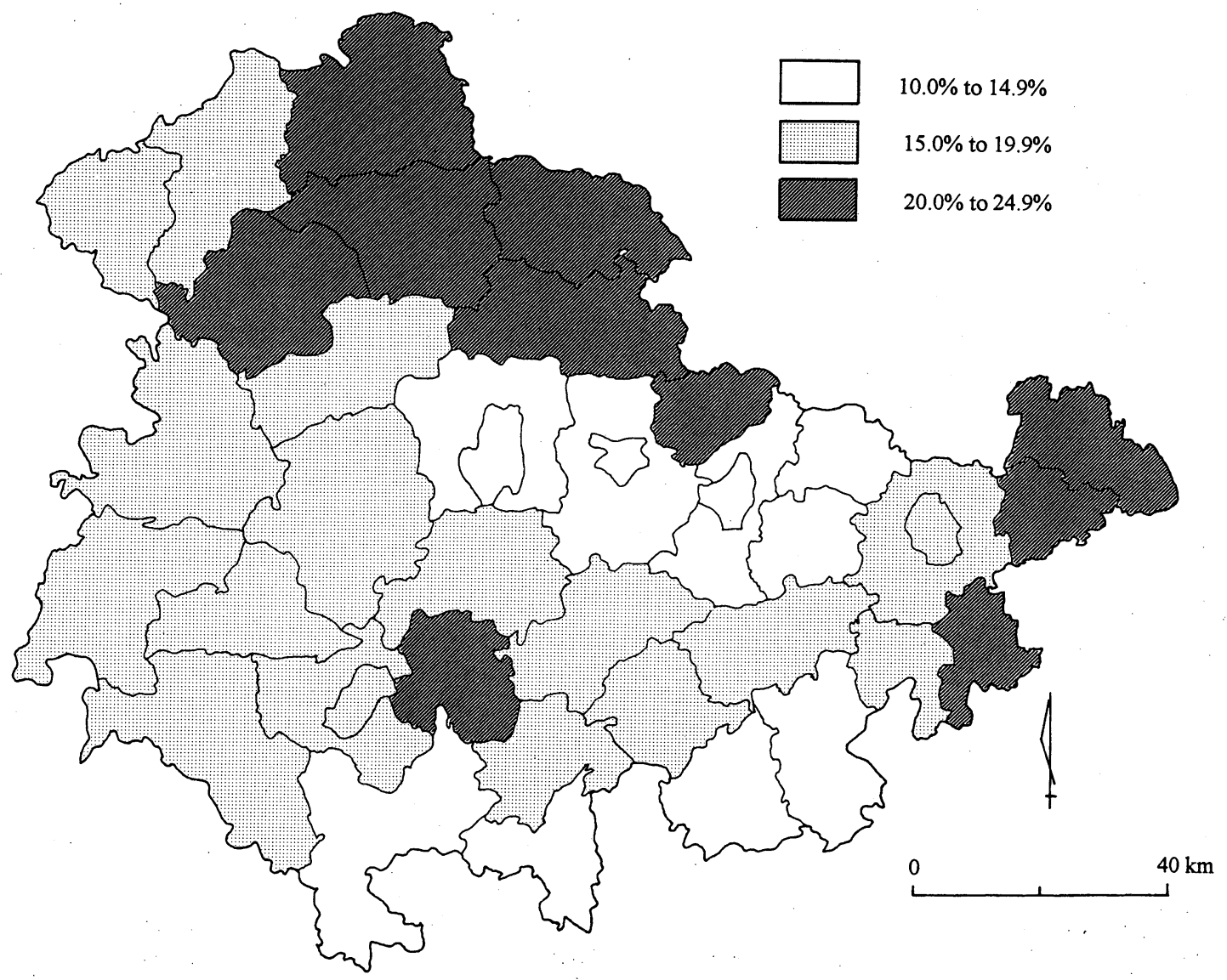

Figure 2. Unemployment rates in Thuringia in December, 1993. Source: Thüringer Landesamt für Statistik, 1994, p. 126

Table 1. Commuters from the Land of Thuringia to northern Bavaria (1992)

\begin{tabular}{|c|c|c|c|c|c|c|c|c|c|c|}
\hline \multirow{3}{*}{$\begin{array}{c}\text { District of } \\
\text { northern } \\
\text { Bavaria }\end{array}$} & \multirow{3}{*}{$\begin{array}{c}\text { Number of } \\
\text { employee }\end{array}$} & \multicolumn{9}{|c|}{ Commuters from: } \\
\hline & & \multirow{2}{*}{$\begin{array}{c}\text { Former } \\
\text { East } \\
\text { Germany }\end{array}$} & \multicolumn{2}{|c|}{ District Erfurt } & \multicolumn{2}{|c|}{ District Jena } & \multicolumn{2}{|c|}{ District Suhl } & \multicolumn{2}{|c|}{ District Gera } \\
\hline & & & person & $\%$ & person & $\%$ & person & $\%$ & person & $\%$ \\
\hline Ansbach & 94,403 & 820 & 29 & 3.5 & 49 & 6.0 & 90 & 11.0 & 50 & 6.1 \\
\hline Aschaffenburg & 123,426 & 1,011 & 68 & 6.7 & 65 & 6.4 & 178 & 17.6 & 42 & 4.2 \\
\hline Bamberg & 95,477 & 1,277 & 48 & 3.8 & 223 & 17.5 & 342 & 26.8 & 77 & 6.0 \\
\hline Bayreuth & 94,707 & 2,588 & 38 & 1.5 & 318 & 12.3 & 182 & 7.0 & 478 & 18.5 \\
\hline Coburg. & 123,616 & 12,715 & 81 & 0.6 & 771 & 6.1 & 10,630 & 83.6 & 784 & 6.2 \\
\hline Hof & 108,716 & 7,375 & 17 & 0.2 & 170 & 2.3 & 29 & 0.4 & 2,470 & 33.5 \\
\hline Nürnberg & 528,866 & 7,299 & 207 & 2.8 & 648 & 8.9 & 810 & 11.1 & 788 & 10.8 \\
\hline Regensburg & 173,274 & 2,533 & 77 & 3.0 & 117 & 4.6 & 87 & 3.4 & 204 & 8.1 \\
\hline Schwandorf & 125,544 & 1,222 & 19 & 1.6 & 58 & 4.7 & 56 & 4.6 & 91 & 7.4 \\
\hline Schweinfurt & 151,332 & 4,938 & 75 & 1.5 & 77 & 1.6 & 4,289 & 86.9 & 33 & 0.7 \\
\hline Weiden & 74,604 & 668 & 6 & 0.9 & 33 & 4.9 & 17 & 2.5 & 71 & 10.66 \\
\hline Weissenburg & 50,477 & 302 & 14 & 4.6 & 34 & 11.3 & 17 & 5.6 & 24 & 7.9 \\
\hline Würzburg & 170,757 & 1,386 & 61 & 4.4 & 82 & 5.9 & 494 & 35.6 & 36 & 2.6 \\
\hline
\end{tabular}


absolute numbers as well as in proportion, from the districts of Suhl and Gera, which are close to the old border, than from the more distant districts of Erfurt and Jena. One notices that, while many commuters from Suhl go to Coburg and Schweinfurt, most commuters from Gera go to Hof, which is followed by Nürnberg and then Coburg. Employment is chosen according to proximity and commuting convenience.

In the following we look at the village of Eicha, which is close to the old border and examine how the employment of its inhabitants has actually changed with reunification.

\section{Changes in agricultural and non- agricultural employment in Eicha, Southwest Thuringia}

\section{Agriculture in Eicha and its transformation}

Table 2 shows that the amount of land owned by each farmer in Eicha in 1945 was very small. The reform of agriculture and agricultural communities, in particular attempts to collectivize agriculture, began right after the war in the $\mathrm{DDR}^{2}$. First, as in other areas of East Germany, a MAS (machine station) was established close to Eicha, in the village of Streufendorf to the East. The MAS built later in the village of
Linden was also under the jurisdiction of Eicha. It had two technicians (Pioniere), a bulldozer, tractors, etc. ${ }^{3}$ The MAS were afterwards turned into MTS (machine-tractor stations) supporting the later LPGs (Landwirtschaftliche Produktions Genossenschaften, Agricultural Production Collectives) and being administered by them.

The first LPG in this area was established in the village of Bedheim in 1952, but had to be dissolved the following year because of strong resistance from the farmers against collectivization. Similar was the case of the LPG in Linden in 1953, which was started with 36 farmers, but soon lost 16 of them. Because of this resistance the founding of the LPG that would eventually comprise all 7 villages in this region had to wait until 1960, when an LPG was started in Gleichamberg. In Eicha the LPG "Bluhendes Land" was established in 1959. It started small, with 5 farmers on 32 ha of land, but by 1960 all farmers were taking part.

As one can see in Fig. 3, the first LPGs in this region were small in scale, comprising single villages. The degree of collectivization was low, as in type I LPG, in which only use of land is collectivized, dominated by the one exception of a type III LPG, in which animal husbandary as well as plant production is collectivized, at Linden ${ }^{4}$.

Table 2. Number of farms by size in Eicha in 1945

\begin{tabular}{ccccccc}
\hline & $0-0.9$ ha & $1.0-1.9$ ha & $2.0-4.9$ ha & $5.0-9.9$ ha & 10.0 ha- \\
\hline \multirow{2}{*}{ Number of farms } & 17 & 7 & 25 & 18 & 7 \\
\hline
\end{tabular}

Source: Data from the village office of Einheitsgemeinde Gleichamberg

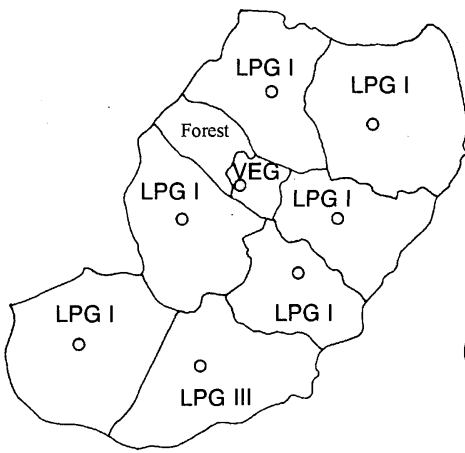

(1) 1960

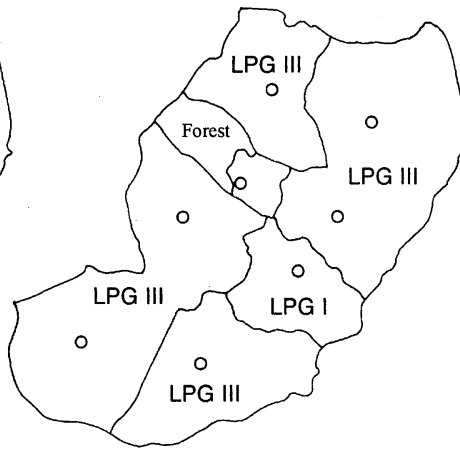

(2) 1972

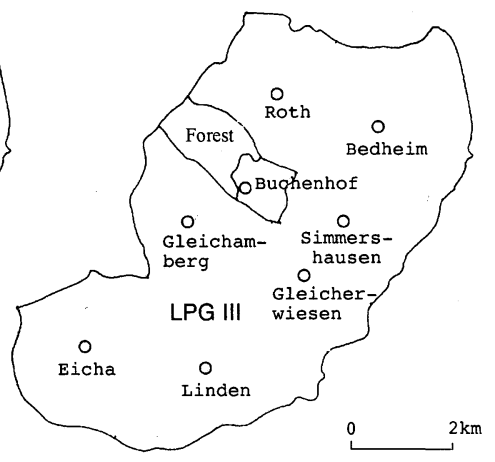

(3) 1987

Figure 3. Changing LPGs in the area around Eicha. Source: LPG “Zuchtzentrum” Linden Gleichamberg, 1989, p. 18, p. 21, p. 33 
If one considers that by 1955 the percentage of type III LPGs in all of East Germany was $77 \%$ in terms of operating units, and $93 \%$ in terms of cultivated area (Klemm, 1980, Appendix p. 12), one sees that collectivization in this region was delayed.

As collectivization was taking place, in 1953, a zone within $5 \mathrm{~km}$ from the border was declared prohibited (Sperrgebiet), with strict restrictions on movement and construction (Kobayashi, 1993, pp. 4-5). At the same time, from $6 / 17 / 1953$, the privileges of a $15 \%$ wage bonus and reduction of agricultural norms by $20 \%$ were accorded this zone (Breitfeld, 1992, p. 15). Nevertheless, the population of Eicha, which had been 546 in 1948, decreased to 356 in 1958, and further decreased to 275 in 1989.

In 1971 the LPG was combined with the neighboring LPG of Gleichamberg, forming the LPG "Größer Gleichberg" and a stable for 400 head of dairy cattle was built in Eicha. The next year the LPGs at Simmershausen and Bedheim were merged in the same way. All LPGs in this region, with the exception of Linden, were turned into type III LPG, which also collectivized animal husbandry (cf. Fig. 3). All 7 villages were merged into a single LPG only from 1986 onwards.

However, even before this, plant production had already been collectivized into the KAP (Kooperative Abteilung Pflanzenproduction, Cooperative Division Plant Production) at Linden, while stock breeding was consolidated into the Linden Gleichamberg Zuchtzentrum. The KAP at Linden had 353 employees and was managing 2,814 ha of land in 1975 . The Linden Gleichamberg Zuchtzentrum in 1974 had 246 employees in 1974, taking care of 3,187 head of cattle (1,655 of these dairy), 3,547 pigs (196 for breeding), and 773 sheep. 599 people altogether were thus working for the LPG at this point. Milk was the main product with $584 \mathrm{t}$ in 1973. In addition cattle and pigs were bred and the LPG was known for its production of superior livestock.

Even during this collectivization farmers were able to cultivate their own plots and keep some cattle of their own, because they were permitted to have 0.5 ha arable land, 2 head of dairy cattle, 2 pigs and 5 sheep. They were able to earn cash by selling fruits, vegetables, milk, pork and eggs on the market.

After reunification the old LPG was reconstructed as the Zuchtzentrum e.G. (Breeding Center, a registered cooperative). In 1993 it is managing 2,242 ha, of which 1,120 ha are used for cereal, 170 ha for winter rapeseed, 530 ha for summer rape, 22 ha for peas, 260 ha are left fallow and the rest is used as pasture. The animal husbandry section has 1,585 head of cattle (787 dairy), 3,700 pigs (680 for breeding). There are 75 employees, 3 of them university trained technicians, 4 technicians, and 9 specialists. Compared to the mid 1970s, when almost 600 people were working in the LPG the number of employees has thus been drastically reduced, to about one eighth.

The two remaining independent farmers in Eicha have chosen farming more out of a sense of nostalgia and should perhaps be classified as hobby farmers. Only one family has rented their land to a Bavarian farmer. The list of reasons why farming by single households has disappeared includes the difficulty of renting out land to the cooperative after having given up agriculture, or having leased it to an outsider, and the problem of access to property that is scattered within the cooperative's land, where roads have disappeared in the course of the enlargement of cultivated area.

\section{Employment structure of Eicha before reuni- fication}

Figures 4-6 show the place of employment of the inhabitants of Eicha by sex, age, and occupational category before reunification. The age used, however, is that of the person in 1994, after reunification. All subjects are present (1994) inhabitants of Eicha. People who left after reunification are not included. But since the population, which was 275 in 1989, 271 in 1991 , and 263 in 1993, has changed very little, it may be assumed that the numbers give a fairly accurate picture of the situation before reunification. In the context of the population movement occasioned by reunification, this relative stability is unusual.

From Fig. 4 one can see that the work places of the inhabitants of Eicha are located mainly in the neighboring towns and villages, and in 


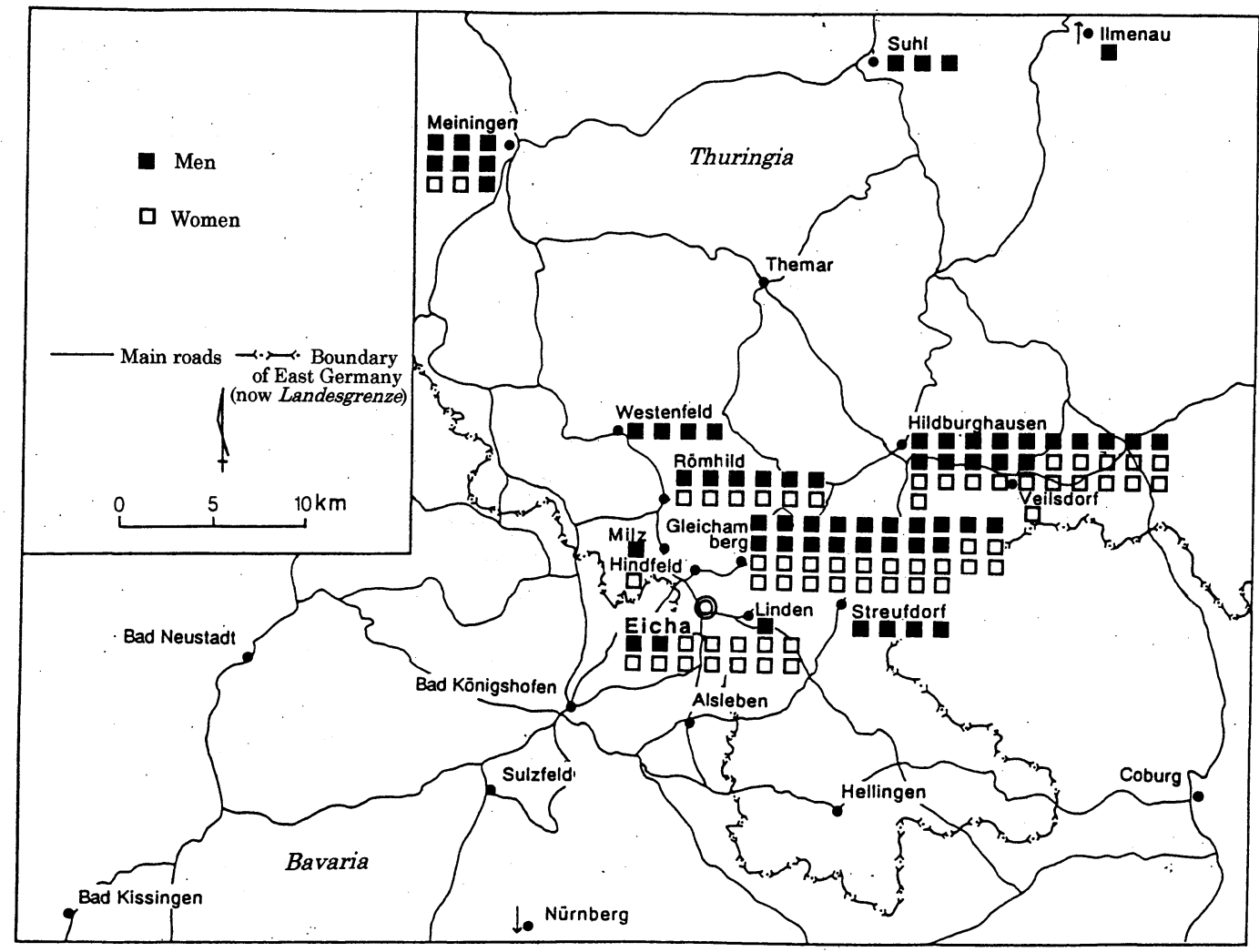

Figure 4. Location of employment for inhabitants of Eicha by sex before reunification Source: interview survey

the regional centers of southwest Thuringia, the cities of Meiningen and Hildburghausen. There is some far distance commuting to Suhl and Ilmenau. Of course there is no commuting to northern Bavaria, south of Eicha. The commuting area is highly asymmetric.

Comparing genders, one sees that women tend to work closer to home. Considering age, one sees that older people work closer to home, while the young and middle-aged commute to more distant places, except for some unskilled old workers in construction (Fig. 5). These tendencies are common in rural areas in all developed industrialized countries, where farmers have taken on outside employment.

Most jobs in Eicha itself are held by women. They either work in the public sector, in offices and day care facilities, or in retail stores (Fig. 6). As for neighboring Gleichamberg, almost everybody works in the LPG. Since, as previously mentioned, Eicha was one of the 7 villages that made up the LPG, this sometimes actually meant work in Eicha itself.

Most of these workers in the LPG were of rather advanced age. Of the 38 LPG workers of Eicha one was younger than 30,3 were in their 30 s, four in their 40 s, 5 in their 50 s, and 25 were older than 60 years. In addition, inside the LPG there was a tendency for young and middle aged employees with vocational education to be in charge of not directly agricultural tasks, such as maintenance of farm machinery, etc., while the physical labor was done by older workers. This confirms the phenomenon, observed in other industrialized countries as well, of the aging of the agricultural work force.

Following Gleichamberg, the most frequent commuting destination was Hildburghausen, the center of the county (Landkreis) with administration and a concentration of industry. Here unskilled workers in construction and manufacturing, most in their 30 s and 40 s, made up about half of all the commuters. The rest were employed in government agencies, offices, 


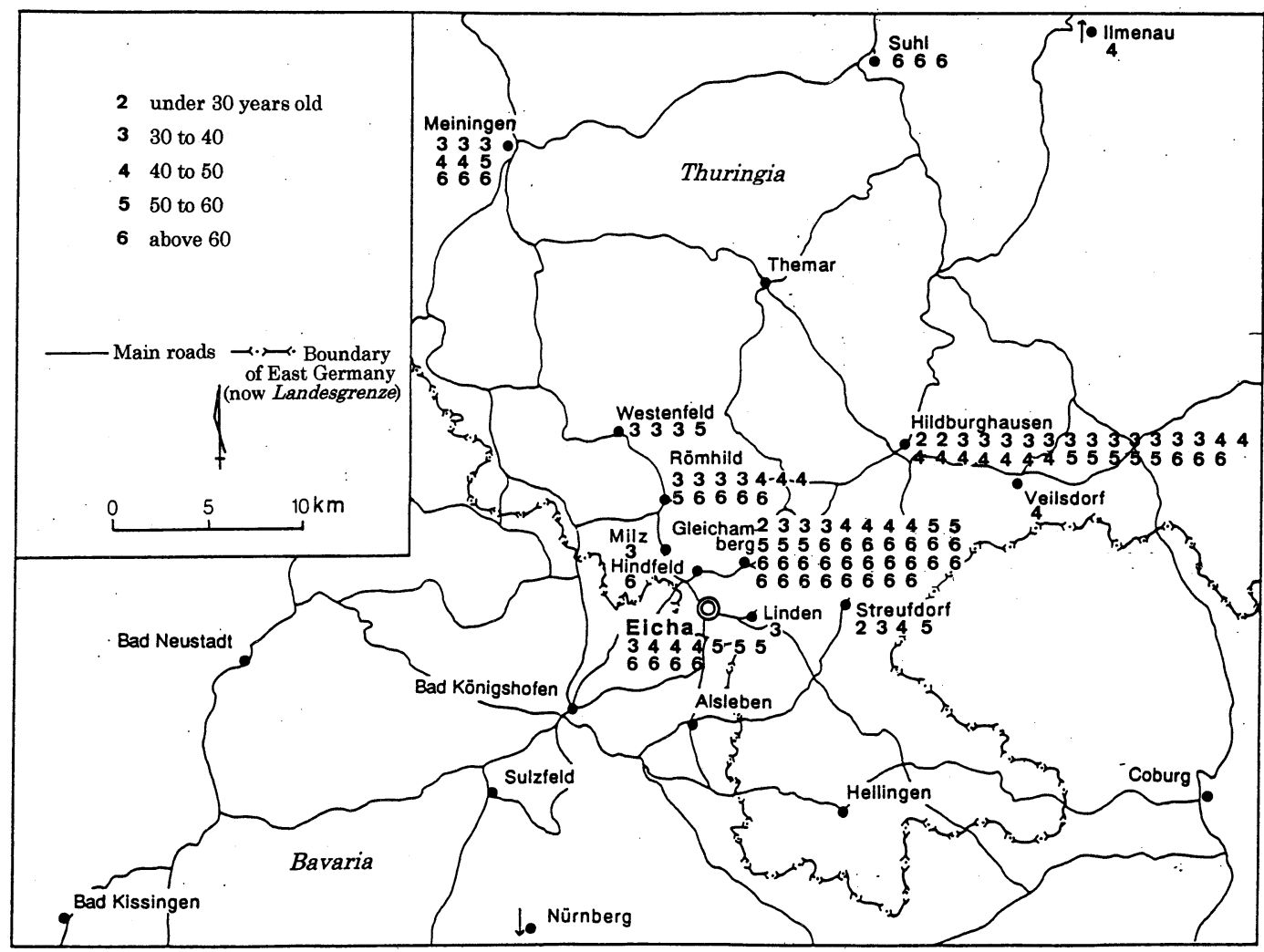

Figure 5. Location of employment for inhabitants of Eicha by age before reunification Source: interview survey

banks, and there were some skilled workers such as masons and truck drivers. Commuters to Meiningen, the central city of the Kreis Meiningen, resembled those to Hildburghausen, although there were fewer. Employment in towns and villages close to Eicha involved traditional handicrafts in the manufacture of ceramics and furniture. Before reunification there were only two cars in Eicha. Commuters used public bus lines or were picked up by company buses.

Even before reunification the tendency towards abandonment of farming among the young and middle aged and their movement into other occupations had already progressed. These younger people were working not only as unskilled laborers but also as engineers, drivers, clerks, and public officials who used public bus lines and factory organized transportation to commute. In the LPG on the other hand, while younger people attended to jobs like the repair of machines, the farm work proper was left to a group of rather aged employees. The aging of the agricultural work force and the trend for members of farm households to take up side jobs, similar to that in agricultural areas in the former West Germany and other industrialized countries had already been established.

\section{Employment structure of Eicha after reunific- ation}

Figures 7 through 9 show the employment of the inhabitants of Eicha in 1994, after reunification, analyzed according to sex, age, and occupational category, as was done above for the situation before reunification.

There is an obvious effect from the opening of the border, as new employment opportunities in Bavaria have become available (Fig.7). On the other hand, the total number of people with jobs in former East Germany has fallen drastically and long distance commuting to Ilmenau and Suhl has completely disappeared. 


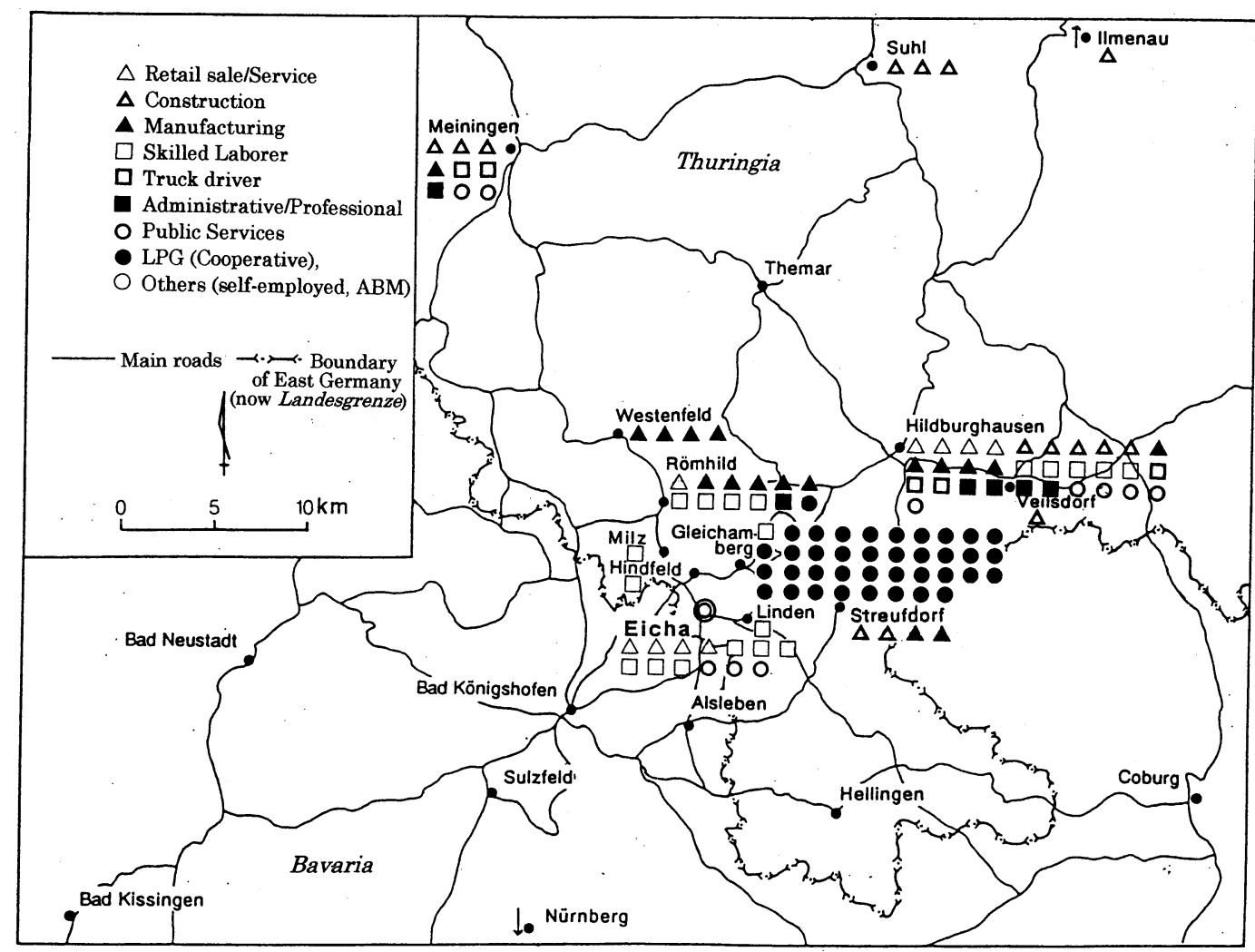

Figure 6. Location of employment for inhabitants of Eicha by occupational category before reunification Source: interview survey

The commuting area has acquired the usual circular shape, while the center has shifted to the south. The difference of distance to commute between genders has become smaller.

Figure 8 shows that the number of people employed among the elderly has markedly decreased. Most of them became retirees (Rentner) or took early retirement (Frührentner), thus disappearing from the labor market. On the other hand, those below the age of 30 , with only one exception, all work in Bavaria, in particular Bad Königshofen. Many of them were still in school when reunification took place and when they were looking for employment for the first time, companies in Bavaria were already among their possible choices.

Looking at occupations we find that there are only 4 who switched from the LPG to the new cooperative: one each in their 30 s and 40 s, two in their 50s (Figure. 9). Besides that, one in his twenties has started at the cooperative in Hellingen. Change to other occupations has not progressed much: only one driver (30s) and one manufacturing worker (40s). From among the other LPG workers a couple in their 60s have opened a restaurant in the village, one each in their 30 s and 40 s are without employment, one each in their 30 s and 50 s are participating in ABM (Arbeitsbeschaffungsmaßnahme), a work program in which they sweep streets, etc. The remaining workers in their 50s and 60s have gone into retirement or early retirement. But although they are retired they do have opportunities to grow vegetables in their own plots and raise animals, especially pigs. One can say that the employment situation of households with older members doing farming and younger people taking on outside work has remained unaltered from before reunification.

Among the young and middle aged there were only 8 who did not change jobs after reunification. There was, however, a tendency that the same skills were used in the new job as in the old. This applies to those who found 


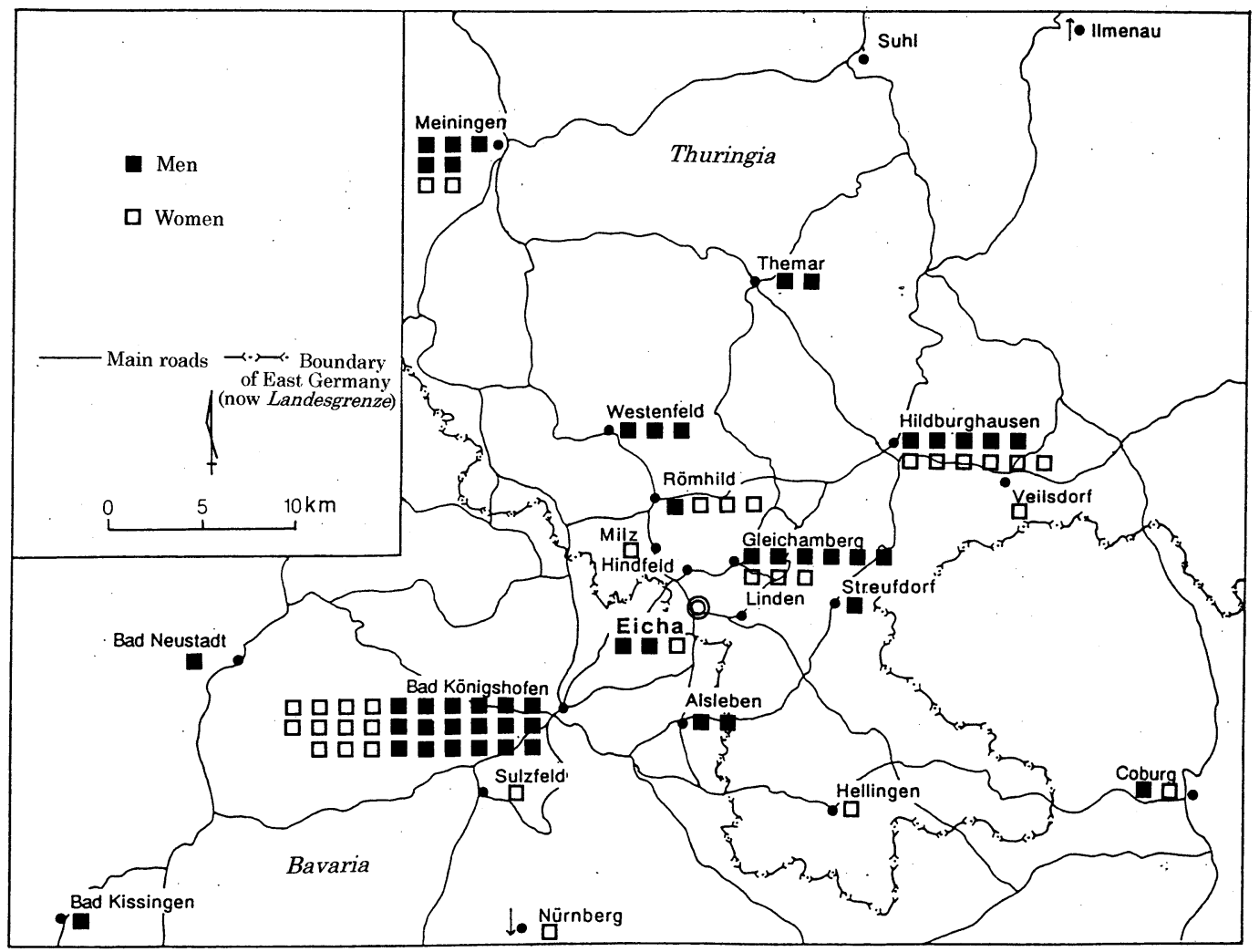

Figure 7. Location of employment for inhabitants of Eicha by sex after reunification Source: interview survey

employment in Bavaria as well. There are the examples of an office worker from former East Germany who became an office worker in Bad Königshofen, a former electrician who works as an electrician, and a kindergarten teacher. On the other hand, some people work as unskilled workers in construction. These people will probably change their jobs to get a more steady occupation with higher income.

Some young people found new jobs in East Germany which were identical or similar to their previous occupations, while some who became unemployed looked for work in Bad Königshofen or Coburg in Bavaria. They too, however, often ended up in jobs where they could use their old skills. They now commute in their own cars; only a few commute by company bus to distant Nürnberg, etc.

The LPG was turned into a cooperative where for the most part only younger people with skills like machine repair were reemployed. The older employees of the LPG were let go, but since they took retirement, the rate of unemployment stayed low. All land, except for two remaining independent farms and one where the land was rented out to a farmer from Bavaria, was leased to the local LPG.

\section{Conclusion}

In the rural areas of southwestern Thuringia, unfavorable natural conditions and the development of industry have produced traditionally mixed small-scale operations in agriculture. These were further marginalized by the enforcement of strict border control during the DDR period.

Because of these circumstances one could observe in Eicha, even before reunification, a declining population trend, a process of young people leaving the farm for other employment and a tendency for people to commute by bus to work in surrounding towns and villages. On the other hand the aging of LPG workers was 


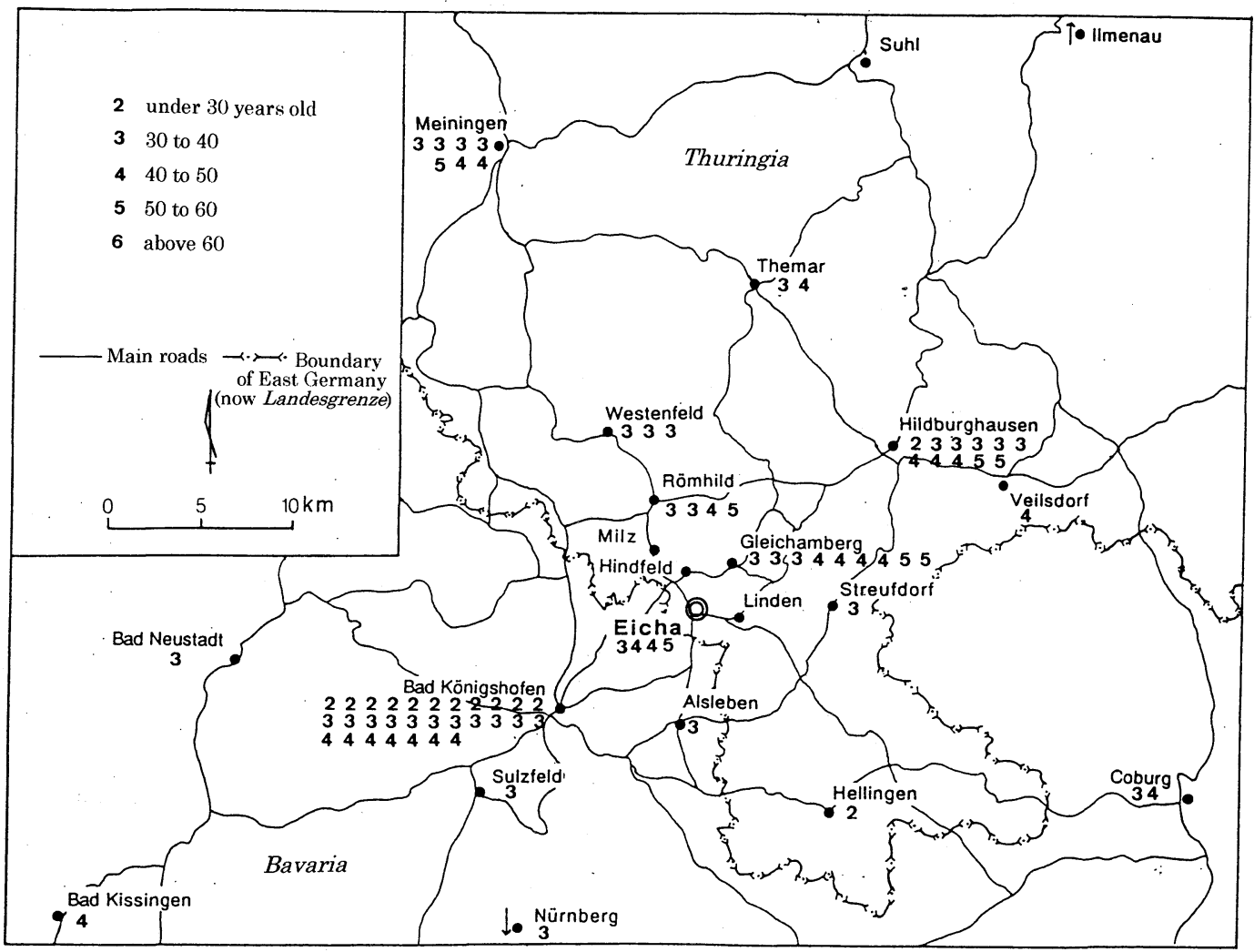

Figure 8. Location of employment for inhabitants of Eicha by age after reunification Source: interview survey

conspicuous. One can say that the aging of the agricultural work force and the process of acquiring non-agricultural employment by members of farm households, similar to that in former West Germany and other industrialized countries, had already begun.

Some younger people found the same kind of job, or a similar one, within the old East Germany, while those who became unemployed looked for work in Bavaria after reunification. The latter, too, were often able to use their old skills. They now commute by private car. The LPG became a cooperative that reemployed younger skilled workers, while the older ones were let go and became pensioners. All land is leased to the cooperative, except for two independent farms and one where the land is leased by a farmer from Bavaria. In spite of the radical political changes, the basic employment structure of the villages in this area remains unchanged.

It can be hypothesized that the small-scale farms brought about by the equal division inheritance system and the development of traditional native industries, etc., in which this area differs from the North of former East Germany, sustained this structure. The circumstance that this area is located close to the old border has provided significant further support to this structure by virtue of the fact that the stratum of unemployed brought about by the collapse of East German companies after reunification was able to take advantage of employment opportunities in former West Germany.

From the above it follows that the rural areas of southwestern Thuringia should be understood as possessing characteristics that make them quite distinct from the northern part of former East Germany. An investigation of employment conditions before the war and comparison with similar areas of former West Germany should prove illuminating.

(Received Mar. 29, 1997)

(Accepted Oct. 10, 1997) 


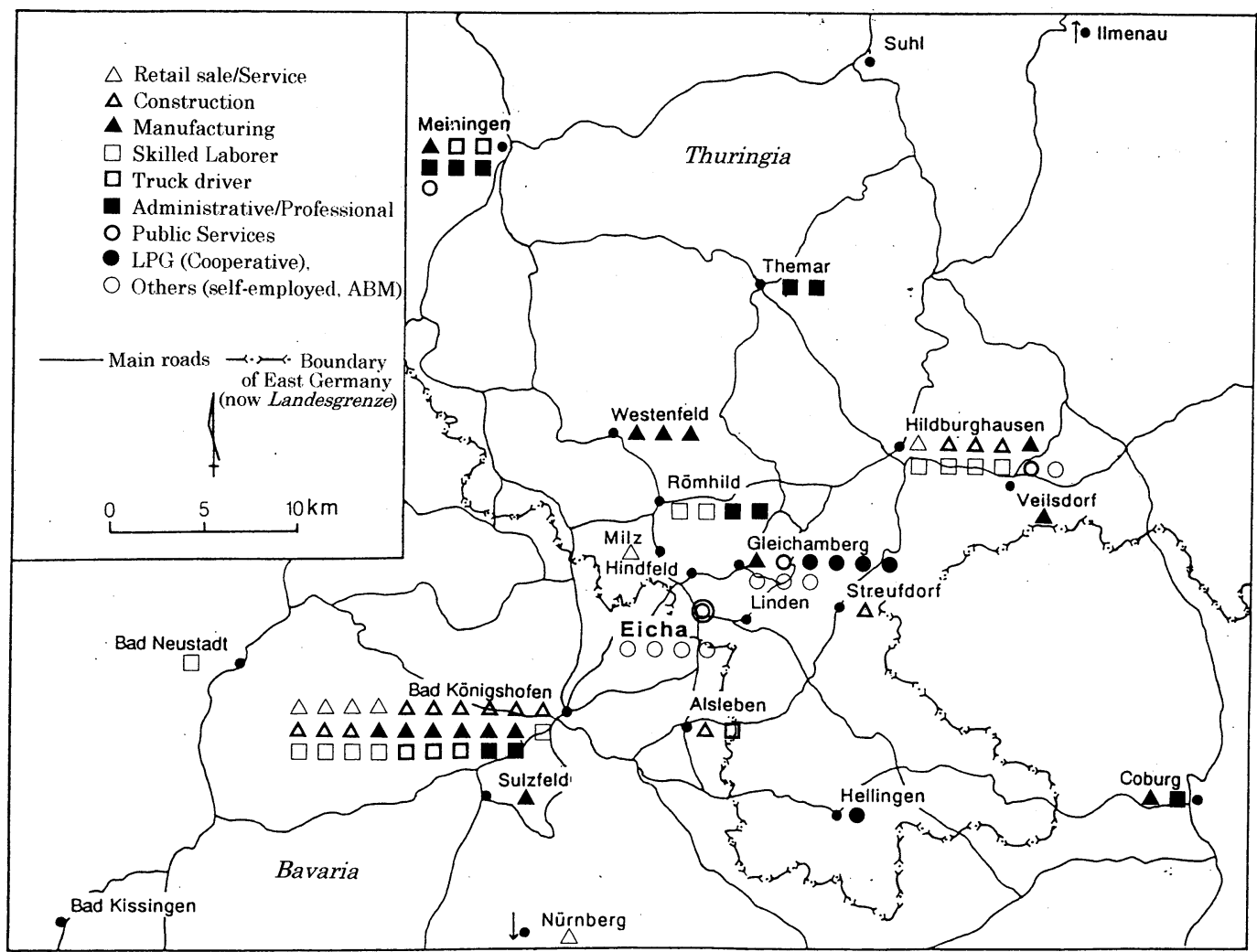

Figure 9. Location of employment for inhabitants of Eicha by occupational category after reunification Source: interview survey

\section{Acknowledgement}

I am indebted to Prof. Dr. Jörg Mair and Prof. Dr. Peter Meusburger for the research of this paper. Thanks are also due to Mr. Zimmermann and other people in Eicha, who were helpful during the field research. This research project was supported by Grant-in-Aid for International Scientific Research of the Ministry of Education, Science and Culture of Japan (Grant No. 04041053)

\section{Notes}

1. According to the village office of Einheitsgemeinde Gleichamberg

2. Klemm, 1980, has more on this process.

3. LPG "Zuchtzentrum" Linden Gleichamberg, 1989. The following also according to the same author and interviews.

4. The three types of LPG are, according to Klemm, 1980, pp. 189-190:

Type I: Use of land, in other words, plant production, is collectivized. Livestock, machines and buildings belong to individual farmers.
Income is divided $60 \%$ according to labor invested by members of the collective, $40 \%$ according to land provided.

Type II: Not only land, but also the means of production like machines and work animals are collectivized. Animal husbandry is still done by individuals. Income is divided $70 \%$ according to labor, $30 \%$ according to land.

Type III: Except for individually managed parts (limited to 0.5 ha arable land, 2 head of dairy cattle, 2 pigs and 5 sheep) animal husbandary as well as plant production is collectivized. Income is divided at least $80 \%$ according to labor.

\section{References}

Breitfeld, K., Gans, P., Grundmann, L., Hartung, A., Herfert, G., Müller, E., Opp, C., Schmidt, W., Taege, G. and Wollkopf, M. (1992): Das vereinte Deutschland-Eine Kleine Geographie. Institut für Länderkunde, Leipzig, 88p.

Heunemann, G. hrsg. (1992): Landesreport Thüringen. Verlag Die Wirtschaft, Berlin, 202p.

Klemm, V., translated by Ohyabu, T. and Murata, 
T. (1980): Doitsu Nougyoushi (German Agricultural History). Ohtsuki Syoten, 233p. (J) (Klemm, V. (1978): Agrargeschichte, Von den bürgerlichen Agrarreformern zur sozialistischen Landwirtschaft in der $D D R$. VEB Deutscher Landwirtschaftsverlag, Berlin.)

Kobayashi, K. (1993): Tougou Doitsu no Hikari to Kage (Lights and Shadows in Unified Germany). Ninomiya Syoten, 210p. (J)

LPG "Zuchtzentrum" Linden Gleichamberg ed. (1989):

Betiräge zur Geschichte der Entwicklung der sozialistischen Landwirtschaft im östlichen Gleichberggebiet 1953-1988. 47p.

Sasaki, H. (1994): Toy Industry at Sonnenberg in Thüringer Wald, Germany. Area Studies Tsukuba, $12,1-26 .(\mathrm{J})$

Scherf, K. et. al. (eds.) (1990): DDR-Ökonomische und soziale Geographie. Haack, Gotha, 516p.

Thüringer Landesamt für Statistik (1994): Statistisches Jahrbuch Thüringen Ausgabe 1994, 2. Jahrgang. 527p. 